\title{
GC/MS Analysis and Bioactive Properties of Extracts Obtained from Clusia minor L. Leaves
}

Raisa Mangas Marín ${ }^{1, *}$, Rodny Montes de Oca Porto ${ }^{2}$, Maria Elisabeth Herrera Paredes ${ }^{3}$, Adonis Bello Alarcón ${ }^{3}$, Ivones Hernández Balmaseda ${ }^{4}$, Roberto Menéndez Soto del Valle ${ }^{5}$, Miriam Teresa Paz Lopes ${ }^{6}$, Idania Rodeiro Guerra ${ }^{4, *}$

${ }^{1}$ Food and Pharmacy Institute (IFAL), University of Havana, Ave. 23, 21425, La Lisa, CP. 13600, Havana, Cuba,

${ }^{2}$ Antidoping Laboratory, Institute of Sport Medicine, Ave. 100 and Aldabó, Boyeros, CP 10 800, Havana, Cuba.

${ }^{3}$ Faculty of Chemical Sciences, University of Guayaquil, Ciudadela Universitaria Dr. Salvador Allende, Guayaquil, Ecuador.

${ }^{4}$ Department of Pharmacology, Institute of Marine Sciences (ICIMAR), Loma 14, Alturas del Vedado, Plaza de la Revolución, CP 10 600, Havana, Cuba.

${ }^{5}$ Center of Neurosciences (CNEURO), Ave 25 and 158, 15202, Playa, CP. 11600, Havana, Cuba.

${ }^{6}$ Department of Pharmacology, Laboratory of Antitumor Substances, Biological Science Institute (ICB), Federal University Minas Gerais (UFMG), 486, 31270-901, Belo Horizonte, Brazil

*Corresponding author: E-mail address: raisamm80@gmail.com (R. Mangas), dania.rodeiro@infomed.sld.cu (I. Rodeiro)

Received April 16 ${ }^{\text {th }}, 2018$; Accepted October 16 ${ }^{\text {th }}, 2018$.

DOI: http://dx.doi.org/10.29356/jmcs.v62i4.544

\begin{abstract}
Clusia minor L. is traditionally used to treat many disorders that including pain and inflammation such as sores and warts. Four extracts from the leaves of the plant were prepared: hexane (A), ethyl acetate (B), methanol (C) and ethanol (E). GC/MS analysis of extracts B and C led to the identification of thirty-three and twenty-seven compounds, respectively. The presence of vitamin $\mathrm{E}$ and lupeol was relevant in both extracts. All extracts showed effective radical scavenger properties in the 2,2-diphenyl-2-picryl-hydrazyl (DPPH) assay, being extract $\mathrm{E}$ the most promissory $\left(\mathrm{IC}_{50}=10.25 \mu \mathrm{g} / \mathrm{mL}\right)$. Extracts $\mathrm{A}, \mathrm{C}$ and $\mathrm{E}$, administered topically $(0.5-4 \mathrm{mg}$ per ear), significantly reduced ear edema induced by croton oil at $4 \mathrm{mg}$ per ear, meanwhile, extract $\mathrm{B}$ was able to significantly reduce the inflammation at the dose of $2 \mathrm{mg}$ per ear. The cytotoxic activity of the extracts was evaluated against four cell lines. Extract B showed the most cytotoxicity effect, with $\mathrm{IC}_{50}$ values in the range of $32.01-203.5 \mu \mathrm{g} / \mathrm{mL}$. In addition, no acute oral toxicity after mice exposure to the four extracts was observed. The results suggest Clusia minor L. may be an excellent potential source of new bioactive agents for the development of new medicinal agents.
\end{abstract}

Keywords: GC/MS analysis; antioxidant; anti-inflammatory; cytotoxicity; acute oral toxicity.

Resumen. La especie Clusia minor L. se usa tradicionalmente para tratar algunos trastornos que incluyen dolor e inflamación, como son las llagas y verrugas. Se prepararon cuatro extractos a partir de las hojas de la planta: hexano (A), acetato de etilo (B), metanol (C) y etanol (E). El análisis por CG/EM de los extractos B y C permitieron la identificación de 33 y 27 compuestos, respectivamente. La presencia de vitamina E y lupeol fue relevante en ambos extractos. Todos los extractos mostraron capacidad secuestradora del radical 2,2difenil-2-picril-hidrazilo (DPPH), siendo el extracto $\mathrm{E}$ el más prometedor $\left(\mathrm{IC}_{50}=10,25 \mu \mathrm{g} / \mathrm{ml}\right)$. Los extractos A, C y E, administrados tópicamente (0,5-4 mg por oreja), redujeron significativamente el edema de oreja inducido por aceite de crotón a $4 \mathrm{mg}$ por oreja; mientras que el extracto B lo logró a la dosis de $2 \mathrm{mg}$ por 
oreja. También fue evaluada la actividad citotóxica de los extractos contra cuatro líneas celulares. El extracto B mostró el mayor efecto de citotoxicidad, con valores de $\mathrm{IC}_{50}$ en el rango de 32,01-203,5 $\mu \mathrm{g} / \mathrm{mL}$. Además, no se observó toxicidad aguda por vía oral después de la exposición de los ratones a los extractos. Los resultados sugieren que esta especie puede ser una fuente potencial de nuevos agentes bioactivos para desarrollar agentes medicinales.

Palabras clave: CG/EM; antioxidante; anti-inflamatorio; citotoxicidad; toxicidad aguda oral.

\section{Abbreviations}

Abs, absorbance; A, hexane extract; B, ethyl acetate extract; C, methanol extract; E, ethanol extract; DMEM, Dulbecco's modified Eagle's medium; DMSO, dimethyl sulphoxide; DPPH, 2,2-Diphenyl-2picrylhydrazyl; $\mathrm{IC}_{50}$, half maximal inhibitory concentration; GC/MS, Gas chromatography-mass spectrometry; MTT, 3-(4,5-dimethylthiazol-2-yl)-2,5-diphenyltetrazolium bromide; RT, retention time.

\section{Introduction}

The Clusiaceae family is characterized by the presence of metabolites with complexity and structural variety and different biological activities. The genus Clusia (Clusiaceae) comprises about 250-300 species [1] and in Cuba, it is one of the genus most represented into of the family, including Garcinia and Calophyllum. For several years, Clusia species have been used in folk medicine to treat various diseases, mainly inflammatory and pain illnesses [2]. The specie C. minor (Quiripití) is traditionally used for the treatment of sores (latex) and warts (leaves) [3], probably due to its anti-inflammatory and antioxidant properties.

Phytochemical studies derived from this genus have revealed the occurrence of polyisoprenylated benzophenones as major metabolites identified [4-7]. In addition, other metabolites have also been described to be present in the genus, such as flavonoids $[4,8-10]$, terpenes $[8,10,11]$ and sterols $[10,11]$. Some of these compounds and extracts obtained from Clusia species have presented antioxidant [9, 12], antiinflammatory [13], antibacterial [6,10] and antitumor activities [8, 14].

Previously, three polyprenylated benzophenones derivatives (named propolone D, hyperibone B and garcinielliptone I) were isolated from C. minor L. fresh fruits [15]. In other way, GC/MS analysis of the hexane extract from its leaves showed the presence of triterpenoids $(\alpha, \beta$-amyrins, lupeol, friedelin, epifriedelinol), sterols ( $\beta$-sitosterol, stigmasterol) and vitamin E as major compounds [16]. Meanwhile, the ethanolic extract analysis led to the identification of sixteen compounds, mainly: triterpenes, steroids and vitamin $\mathrm{E}$. The most commonly compounds found were $\beta$-sitosterol (14.04\%), $\alpha$-amyrin (11.94\%), vitamin E $(8.44 \%)$ and $\beta$-amyrin (7.82\%) (unpublished data).

This study reports the chemical composition of polar extracts (B and C) from C. minor L. leaves by means of Gas Chromatography/Mass Spectrometry. Also, a screening of the pharmaco-toxicological effects of the four extracts obtained from this specie was performed.

\section{Experimental}

\section{Chemicals}

All reagents and solvents used for gas chromatography/mass spectrometry analysis were analytical quality and obtained from Aldrich (Milwaukee, MN, USA). Culture media and complements were purchased from GIBCO (Gibco BRL, Paisley, UK). The other chemicals were purchased from Sigma Aldrich.

\section{Plant material}


Leaves of Clusia minor L. were collected in September 2016 at the National Botanical Garden, Cuba. This specie was identified by Dr. Cristina Panfet and a voucher specimen (Herbarium No. 482) was deposited at the herbarium of the Tropical Agricultural Fundamental Research Institute.

\section{Preparation of the extracts}

Dried and grounded leaves ( $30 \mathrm{~g})$ of C. minor L. were successively extracted with hexane (A), ethyl acetate (B) and methanol (C). Also, $32 \mathrm{~g}$ of dried powdered leaves of $C$. minor L. were successively extracted with ethanol absolute (E). All extracts were obtained by static maceration at room temperature three times during seven days each. Solvents were replaced every two days. Extracts were filtered and concentrated to dryness under reduced pressure at $45^{\circ} \mathrm{C}$ using a rotary vacuum evaporator. Dried extracts were weighed and stored for further analysis. One mg of the dried residue of extracts B and $\mathrm{C}$ was dissolved in $1 \mathrm{~mL}$ of both ethyl acetate and methanol, and also it was dissolved in $0.5 \mathrm{~mL}$ of internal standard solution (tridecanoic acid at $0.05 \mathrm{mg} / \mathrm{mL}$ in chloroform). These extracts were analyzed by GC/MS.

\section{GC/MS analysis}

For the analysis, the volume of injection was $1 \mu \mathrm{L}$ without derivatization. The sample was separated on a fused-silica capillary column (SPB-5, $15 \mathrm{~m}$ x $0.25 \mathrm{~mm}$ i.d., film thickness $0.10 \mu \mathrm{m}$, Supelco, PA, USA) installed on a Hewlett-Packard 6890 gas chromatograph (Palo Alto, CA, USA) coupled with a HewlettPackard 5973 quadrupole mass spectrometer (GC/MS).

The oven temperature was programmed as follows: isothermic initially at $60^{\circ} \mathrm{C}$ for 2 minutes, then increased up to $100{ }^{\circ} \mathrm{C}$ at $4{ }^{\circ} \mathrm{C} / \mathrm{min}$, then increased up to $290{ }^{\circ} \mathrm{C}$ at $10^{\circ} \mathrm{C} / \mathrm{min}$ and finally isothermic for $5 \mathrm{~min}$. The split injection mode $(1: 10)$ was used. The carrier gas was helium at a constant flow mode rate of 1 $\mathrm{mL} / \mathrm{min}$. The injection port, ion source and interface temperatures were: 280,280 and $150{ }^{\circ} \mathrm{C}$, respectively. The energy of ionization was of $70 \mathrm{eV}$. The mass spectra were obtained in full scan mode since 40 to 700 uma.

The identification of components was accomplished by comparison of retention times (RT) and spectra from available commercial standards (mixtures $\mathrm{C}_{8}$ to $\mathrm{C}_{24}, \alpha$ and $\beta$-amyrins, $\beta$-sitosterol) and similar compound spectra at the libraries NIST98 and Wiley275 MS. Only the components with similarity index of $90 \%$ and above according to databases were considered. All compounds were confirmed by molecular ion peaks and the study of classical fragmentation pattern. In some cases where identical spectra were not found, only the structural type of the component was proposed based on the MS fragmentation. The semiquantification process of major compounds was carried out by internal normalization with the area of each compound. The addition of each area of the compounds corresponds to $100 \%$ area.

\section{Assay of 2,2-Diphenyl-2-picrylhydrazyl (DPPH) scavenging activity}

The antioxidant capacity of the four extracts was measured as DPPH radical scavenging ability according to Tabart [17] with minor modifications. DPPH $(0.075 \mathrm{mg} / \mathrm{mL})$ in ethanol was mixed with the extracts $(10-2000 \mu \mathrm{g} / \mathrm{mL})$ at final volume of $2000 \mu \mathrm{l}$. A control sample (absolute ethanol) and a reference sample (absolute ethanol plus DPPH solution) were used. The decrease in the absorbance (Abs) at $515 \mathrm{~nm}$ was determined in a UV-1201 spectrophotometer (Shimadzu, Japan), until the reaction plateau step was reached. The $\mathrm{IC}_{50}$ values were determined by using GraphPad Prism program Version 5 and it was defined as the total antioxidant compound necessary to decrease the initial DPPH radical concentration by $50 \%$. Their scavenging effect of each extract was calculated as: \% DPPH inhibition $=$ (control Abs - sample Abs)/(control Abs) x 100, were control Abs represent: ethanol Abs + DPPH and sample Abs: sample Abs + DPPH.

\section{MTT assay as a measured of the cytotoxicity effects}

Cytotoxic potential was investigated against the non-tumor cells, BHK-21 (baby hamster kidney) and three tumor cell lines: CT26-WT (murine colon cancer cells), 4T1 (mouse metastatic mammary adenocarcinoma) and EAHy926 (human endothelial cells). Cells diluted in Dulbecco's modified Eagle's medium (DMEM) with $10 \%$ heat-inactivated fetal calf serum were incubated overnight at $37{ }^{\circ} \mathrm{C}$ and $5 \% \mathrm{CO}_{2}$. Then, they were exposed to the extracts $(10-1000 \mu \mathrm{g} / \mathrm{mL})$ for $48 \mathrm{~h}$. The extracts were diluted in DMSO $(0.5 \%)$. Control cells (medium plus DMSO $0.5 \%$ ) were included. Cell viability was assessed using a MTT assay as Mossman et al. [18). MTT was added at $1 \mathrm{mg} / \mathrm{mL}$ final concentration and the cells were incubated 
for $3 \mathrm{~h}$. After aspirating the medium, $100 \mu \mathrm{l}$ of DMSO were added for the dissolution of formazan crystals. The absorbance was read at $540 \mathrm{~nm}$ using a microplate reader. The percentage of inhibition of the MTT reduction was expressed as the percentage of viable cells referred to control cells incubated in the absence of test extracts (negative control, it was considered as $100 \%$ viability value). The values of $\mathrm{IC}_{50}$ were also calculated.

\section{In vivo assays \\ Animals}

Mice were obtained from Center for the Production of Laboratory Animals (CENPALAB, Havana, Cuba). They were kept in a temperature-controlled environment $\left(23^{\circ} \mathrm{C}\right)$ with a $12 \mathrm{~h}$ light-dark cycle, relative humidity 40-70\%, with food and water ad libitum. OF-1 mice (25-30 g) were randomly assigned for each test. The studies were in compliance with Good Laboratory Practice standards. Experiments were conducted in accordance with ethical guidelines for investigations in laboratory animals and were approved by the Ethical Committee for Animal Experimentation of the Institute of Marine Sciences (ICIMAR), Havana, Cuba.

\section{Croton oil-induced mouse ear edema as a measured of inflammation}

Inflammation was induced by topical application of croton oil ( $2 \mathrm{mg}$ in $20 \mu \mathrm{L}$ of acetone) of both surfaces of the right ear of each mouse. The left ear of each mouse received the vehicle (control). Each extract was administered topically (0.5-4 mg per ear in acetone) one hour before croton oil. A group with application of croton oil (negative control) on the right ear and a positive control group that received indomethacin (3 $\mathrm{mg} / 20 \mu \mathrm{L}$ of acetone) were used. The induction of the inflammation lasted five hours and soon after mice were killed by cervical dislocation. A $6 \mathrm{~mm}$ section from each ear was removed with a metal punch and weighed. Ear edema was calculated by subtracting the weight of the left ear (vehicle) from the right ear (treatment), and was expressed as edema weight. Inhibition percentage was expressed as a reduction in weight with respect to the control group [19].

\section{Acute oral toxicity study}

The study was performed according to the ATC protocol described in the OECD Protocol 423 [20]. Four extracts were administered orally via gastric intubation to mice of both sexes at a single dose of 2000 $\mathrm{mg} / \mathrm{kg}$. They were suspended in carboxymethylcellulose $0.5 \%(10 \mathrm{~mL} / \mathrm{kg})$. During experiment, appearance and over behavior were recorded, so changes in skin and fur, eyes and mucous membranes, disturbances on the respiration, circulation, autonomic or central nervous system and behavior pattern were observed. Body weight data was measured at the beginning and the end of the study. The incidence of gross pathological changes observed during the necropsy performed at day 14 was also included.

\section{Statistical analysis}

Data were expressed as the mean $\pm \mathrm{SD}$. For the GC/MS analyses three independent measures were done on five samples. Statistical analysis was performed by Mann-Whitney U test. The percentage of DPPH scavenged, cell viability and inflammation determinations were analyzed by one-way ANOVA, followed by a Dunnett's test for multiple comparisons using the GraphPad Prism Version 5 statistical software package. Frequencies of toxicity signs were compared by means of the Fisher exact probability test. A $p<0.05$ was considered statistically significant.

\section{Results and discussion}

\section{GC/MS analysis of Clusia minor extracts}

The chromatogram of extract B obtained after the GC/MS analysis showed chromatographic peaks from 8 to 23 min approximately and 33 compounds were identified (Fig. 1, Table 1). Several compounds identified in this extract were also present in the extract A [16], suggesting an elevated abundance of this kind of compounds in the leaves of this specie. 


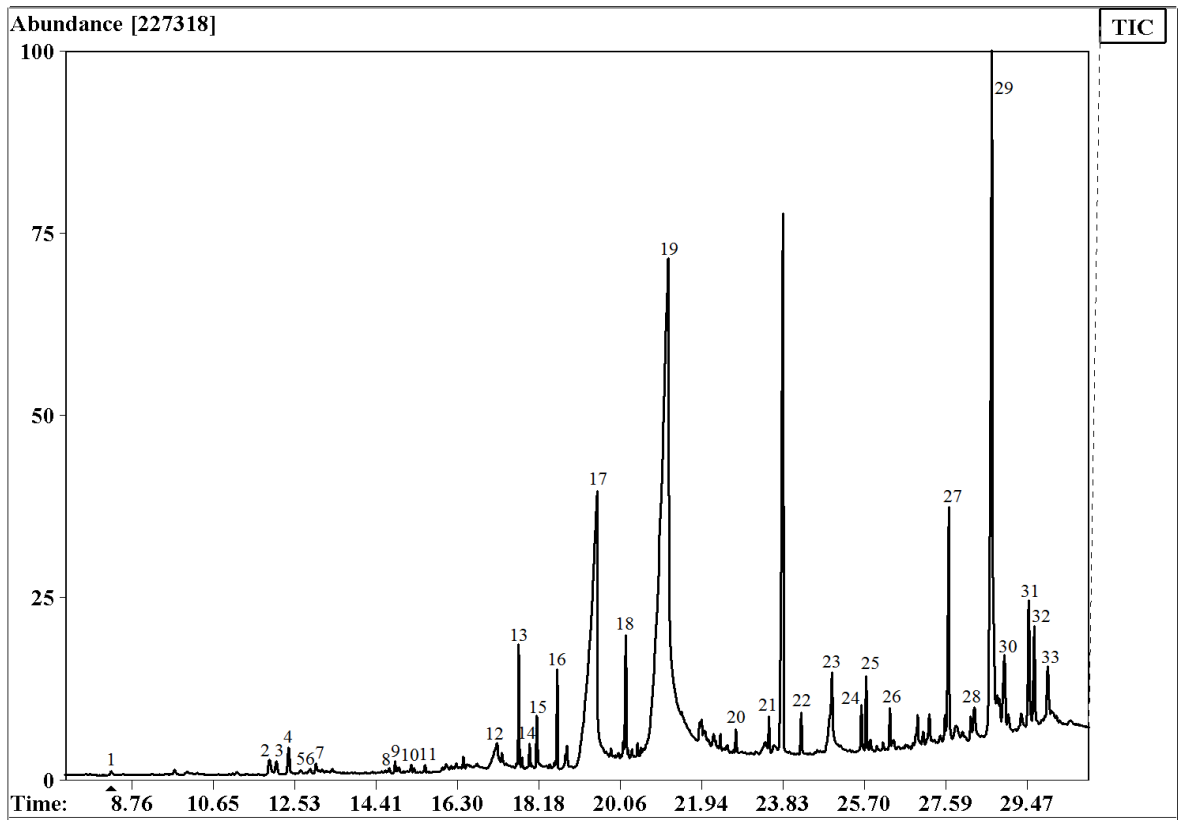

Fig. 1. Chromatogram obtained by GC/MS analysis of extract B from C. minor leaves.

Table 1. Compounds identified in extract B from C. minor leaves by GC/MS.

\begin{tabular}{|c|c|c|c|}
\hline $\begin{array}{c}\text { Peak } \\
\text { No. }\end{array}$ & Compounds & $\begin{array}{c}\text { RT } \\
(\mathbf{m i n})\end{array}$ & $\begin{array}{c}\text { Relative abundance } \\
\mathbf{( \%} \pm \text { SD) }\end{array}$ \\
\hline $\mathbf{1}$ & $\delta$-elemene & 8.293 & $0.050 \pm 0.009$ \\
\hline $\mathbf{2}$ & selin-4,7(11)-diene & 11.957 & $0.361 \pm 0.015$ \\
\hline $\mathbf{3}$ & $\beta$-selinene & 12.116 & $0.285 \pm 0.007$ \\
\hline $\mathbf{4}$ & $\beta$-maaliene & 12.392 & $0.485 \pm 0.022$ \\
\hline $\mathbf{5}$ & $\alpha$-murolene & 12.669 & $0.072 \pm 0.018$ \\
\hline $\mathbf{6}$ & $\alpha$-aorfene & 12.895 & $0.089 \pm 0.054$ \\
\hline $\mathbf{7}$ & 4-hidroxy-3,5-di-tert-butyl toluene & 13.021 & $0.160 \pm 0.010$ \\
\hline $\mathbf{8}$ & aromandrene & 14.874 & $0.140 \pm 0.012$ \\
\hline $\mathbf{9}$ & cycloisolongifolene & 14.931 & $0.075 \pm 0.008$ \\
\hline $\mathbf{1 0}$ & globulol & 15.234 & $0.097 \pm 0.061$ \\
\hline $\mathbf{1 1}$ & cadalin & 15.544 & $0.122 \pm 0.030$ \\
\hline $\mathbf{1 2}$ & tetradecanoic acid (myristic acid) & 17.212 & $0.945 \pm 0.024$ \\
\hline $\mathbf{1 3}$ & neophytadiene & 17.715 & $1.321 \pm 0.005$ \\
\hline $\mathbf{1 4}$ & 2-hexadecene, 3,7,11,15-tetramethyl & 17.791 & $0.119 \pm 0.031$ \\
\hline $\mathbf{1 6}$ & hexadecanoic acid, methyl ester & 18.604 & $1.012 \pm 0.009$ \\
\hline $\mathbf{1 7}$ & hexadecanoic acid & 19.517 & $19.837 \pm 0.005$ \\
\hline $\mathbf{1 8}$ & $9,12,15$, octadecatrienoic acid, methyl ester & 20.188 & $1.460 \pm 0.060$ \\
\hline $\mathbf{2 0}$ & tetracosane & 22.736 & $0.243 \pm 0.011$ \\
\hline $\mathbf{2 1}$ & pentacosane & 23.499 & $0.397 \pm 0.032$ \\
\hline $\mathbf{2 2}$ & hexacosane & 24.245 & $0.536 \pm 0.0012$ \\
\hline $\mathbf{2 3}$ & heptacosane & 24.957 & $1.381 \pm 0.006$ \\
\hline $\mathbf{2 4}$ & octacosane & 25.645 & $0.627 \pm 0.042$ \\
\hline $\mathbf{2 5}$ & squalene & 25.754 & $0.874 \pm 0.032$ \\
\hline $\mathbf{2 6}$ & nonacosane & 26.299 & $0.537 \pm 0.019$ \\
\hline & & & \\
\hline
\end{tabular}




\begin{tabular}{|l|c|c|c|}
\hline $\mathbf{2 7}$ & vitamin E & 27.648 & $3.286 \pm 0.010$ \\
\hline $\mathbf{2 8}$ & stigmasterol & 28.243 & $0.672 \pm 0.054$ \\
\hline $\mathbf{2 9}$ & B-sitosterol & 28.653 & $13.314 \pm 0.021$ \\
\hline $\mathbf{3 0}$ & lupeol & 28.944 & $1.468 \pm 0.011$ \\
\hline $\mathbf{3 1}$ & epifriedelinol & 29.511 & $2.280 \pm 0.058$ \\
\hline $\mathbf{3 2}$ & friedelin & 29.636 & $1.586 \pm 0.015$ \\
\hline $\mathbf{3 3}$ & urs-12-en-28-al & 29.947 & $1.103 \pm 0.052$ \\
\hline
\end{tabular}

A group of minority compounds were characterized from 8 to $16 \mathrm{~min}$ corresponding mainly to sesquiterpenes (aprox. $2 \%$ of total identified compounds). On the other hand, compounds with abundant signal were recorded between 17-30 min corresponding to the majority of compounds ( $98 \%$ of the extract). These substances were identified as straight chain hydrocarbons, pentacyclic triterpenoids derivatives of ursanes, lupanes, and friedelanes presented as alcohol form. Steroids were observed too. Vitamin E represented $3.3 \%$ of this extract, while major compounds found were hexadecanoic acid $(19.8 \%)$ and the steroid $\beta$-sitosterol (13.3\%).

In this extract, two constituents showed mass spectral fragmentation typical for straight chain hydrocarbons, but their structures could not be determined. They were identified as 15 and 19 in the obtained chromatogram (Fig. 1). Comparisons of mass spectra of 19 and 18 (octadecatrienoate methyl ester) showed several coincidences. The molecular ion of compound 18 was $\mathrm{M}^{+} 292 \mathrm{Da}$, while compound 19 had its molecular ion at m/z $278 \mathrm{Da}, 14 \mathrm{Da}$ less than compound 18. Then, compound 19 was proposed as heptadecatrienoate methyl ester, an inferior homologue of octadecatrienoate methyl ester.

Besides, the chromatogram analysis of extract $\mathrm{C}$ showed 27 chromatographic peaks with high abundances (Fig. 2, Table 2). As it can be seen, between 23-25 min straight chain hydrocarbon compounds were found corresponding to $49 \%$ of the extract. Also, vitamin E was observed in this interval with an abundance of $2.5 \%$. Above $28 \mathrm{~min}$ different triterpenoids (lupanes, ursanes, oleananes, friedelanes), tritriacontane and $\beta$-sitosterol were found. The most abundant compounds present in this extract were epifriedelinol (23.7\%) and friedelin (12.7\%).

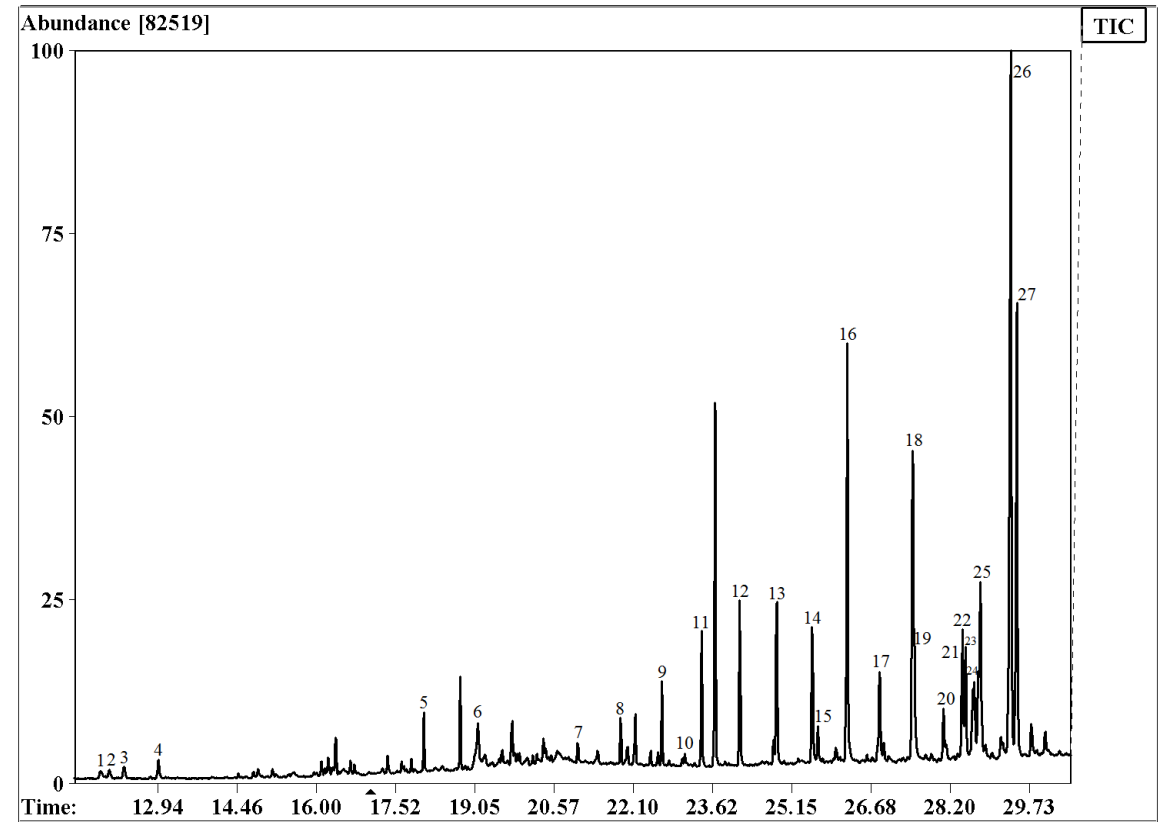

Fig. 2. Chromatogram obtained by GC/MS analysis of extract C from C. minor leaves. 
Table 2. Compounds identified in extract $\mathrm{C}$ from $C$. minor leaves by GC/MS.

\begin{tabular}{|c|c|c|c|}
\hline Peak No. & Compounds & RT (min) & $\begin{array}{c}\text { Relative abundance } \\
(\% \pm \text { SD })\end{array}$ \\
\hline 1 & azulene & 11.848 & $0.364 \pm 0.002$ \\
\hline 2 & eudesma-4(14),11-diene & 12.007 & $0.332 \pm 0.050$ \\
\hline 3 & $\alpha$-selinene & 12.292 & $0.430 \pm 0.031$ \\
\hline 4 & 4-hydroxy-3,5-di-tert-butyl- toluene & 12.954 & $0.599 \pm 0.006$ \\
\hline 5 & 1-hexadecene & 18.059 & $1.205 \pm 0.015$ \\
\hline 6 & hexadecanoic acid & 19.115 & $2.414 \pm 0.044$ \\
\hline 7 & docosane & 21.026 & $0.502 \pm 0.009$ \\
\hline 8 & tricosane & 21.856 & $1.020 \pm 0.026$ \\
\hline 9 & tetracosane & 22.652 & $1.792 \pm 0.012$ \\
\hline 10 & 2,4-bis (phenylethyl)-phenol & 23.096 & $0.181 \pm 0.008$ \\
\hline 11 & pentacosane & 23.415 & $3.149 \pm 0.030$ \\
\hline 12 & hexacosane & 24.153 & $3.566 \pm 0.011$ \\
\hline 13 & heptacosane & 24.865 & $3.940 \pm 0.007$ \\
\hline 14 & octacosane & 25.552 & $3.808 \pm 0.033$ \\
\hline 15 & squalene & 25.653 & $0.947 \pm 0.021$ \\
\hline 16 & nonacosane & 26.210 & $11.042 \pm 0.054$ \\
\hline 17 & triacontane & 26.843 & $1.772 \pm 0.012$ \\
\hline 18 & hentriacontane & 27.480 & $7.928 \pm 0.007$ \\
\hline 19 & vitamin $\mathrm{E}$ & 27.514 & $2.490 \pm 0.060$ \\
\hline 20 & dotriacontane & 28.076 & $1.596 \pm 0.022$ \\
\hline 21 & $\beta$-sitosterol & 28.436 & $3.308 \pm 0.009$ \\
\hline 22 & $\beta$-amyrin & 28.495 & $2.921 \pm 0.012$ \\
\hline 23 & tritriacontane & 28.671 & $1.262 \pm 0.031$ \\
\hline 24 & $\alpha$-amyrin & 28.746 & $1.741 \pm 0.044$ \\
\hline 25 & lupeol & 28.788 & $5.187 \pm 0.013$ \\
\hline 26 & epifriedelinol & 29.375 & $23.770 \pm 0.007$ \\
\hline 27 & friedelin & 29.492 & $12.722 \pm 0.024$ \\
\hline
\end{tabular}


Based on previous results [16], and according to our collected data nonacosane, squalene, vitamin E, $\beta$-sitosterol, lupeol, epifriedelinol and friedelin were found in the three extracts (A, B and C) obtained from this specie of Clusia grown in Cuba.

In the genus Clusia have been identified triterpenoids, such as $\alpha$ and $\beta$ amyrins [16, 22], friedelin $[10,12,16,23]$, aplotaxene [22], oleanolic acid [22, 24], $\alpha$ and $\beta$ friedelinols $[16,22,24]$. Meanwhile, we have reported here the presence of $\alpha$ and $\beta$-amyrins, friedelin, epifriedelinol and lupeol in Clusia minor L. Lupeol was the most abundant triterpene found in the present study (representing 13.7\% of total identified compounds), followed of $\alpha$-amyrin (10\%). These findings confirms the abundance of the triterpenoids in the genus Clusia.

Many of the identified compounds often possess valuable biological activities. Sesquiterpenes have shown antibacterial and antifungal activities, which indicates defensive functions in the plants [21]. Fatty acids and derivatives are known to present antibacterial, anti-inflammatory, anticancer, and antioxidant properties [25-27]. Triterpene alcohols have been demonstrated to possess marked anti-inflammatory activity $[28,29]$ and compounds such as $\alpha$-amyrin, lupeol and cycloartan-type triterpenes are recognized cytotoxic agents [30-32].

Sterols are important constituents of eukaryotes organisms. They play a vital role in plant cellmembranes. In addition, recently the biological role of phytosterols in human and animal health has been established, with emphasis in its immune modulatory activity [33,34]. In this study, only one group of sterols (double bonds at $\mathrm{C}-5$ ) was found after the analysis of extracts B and C. The typical plant sterols, sitosterol and stigmasterol, structurally similar, appeared as major sterol components found. $\beta$-sitosterol has been associated with cardiovascular protection, exerting its effect mainly through increasing the antioxidant defense system and effectively lowering the serum cholesterol levels in humans [35]. Only $\beta$-sitosterol has been reported found previously in the genus $[10,12,22]$ and, stigmasterol was identified for the first time in the genus in the previous study done for this specie [16].

\section{Pharmacological and toxicity screening of Clusia minor extracts}

Traditional uses of $C$. minor $\mathrm{L}$ specie involve antioxidant and anti-inflammatory properties [2]. The type of structures identified in the C. minor $\mathrm{L}$. leaves extracts reinforces this evidence so we decided to evaluate their potential in vitro antioxidant effects by determination its scavenging capacity and antiinflammatory activity in mice.

The data shows that four extracts were able to exhibit DPPH radical scavenging activity. As it shows in Fig. 3, the maximum antioxidant effect $(85 \%)$ was observed for extract $\mathrm{E}$ at $125 \mu \mathrm{g} / \mathrm{mL}$. In addition, this extract showed the lowest $\mathrm{IC}_{50}$ value $(10.25 \pm 8.7 \mu \mathrm{g} / \mathrm{mL})$. As it was previously was explained, extract $\mathrm{E}$ was obtained by absolute ethanol extraction, a high polarity solvent. The ethanol favors the extraction of many phenolic compounds like flavonoids, which have been reported to exhibit strong antioxidant activity [36-40]. As we would have expected, this result matches with compounds identified in this extract by GC-MS analysis (unpublished data). Extracts $\mathrm{B}$ and $\mathrm{C}$ showed also significant antioxidant activity, being its maximum scavenging capacity of 70 and $80 \%$, respectively, at the concentration of $625 \mu \mathrm{g} / \mathrm{mL}$ while, the $\mathrm{IC}_{50}$ values calculated were $126.2 \mu \mathrm{g} / \mathrm{mL} \pm 97.6$ (B) and $198.9 \mu \mathrm{g} / \mathrm{mL} \pm 57.3$ (C) (Fig. 3). Extract A showed a maximum effect around $58 \%$ at $300 \mu \mathrm{g} / \mathrm{mL}\left(\mathrm{IC}_{50}=132 \mu \mathrm{g} / \mathrm{mL}\right.$ ), which was lower than the ones observed for other extracts (B, C and E). These results evidenced that extract polarity may reinforce the capacity to scavenger DPPH. Vitamin E, identified in the extracts, was a common antioxidant and it has strong free radical scavenger capabilities [41]. Other compounds identified in these extracts with recognized antioxidant properties and previously found were stigmasterol [42, 43], $\beta$-sitosterol [44-46], neophytadiene [47]. 

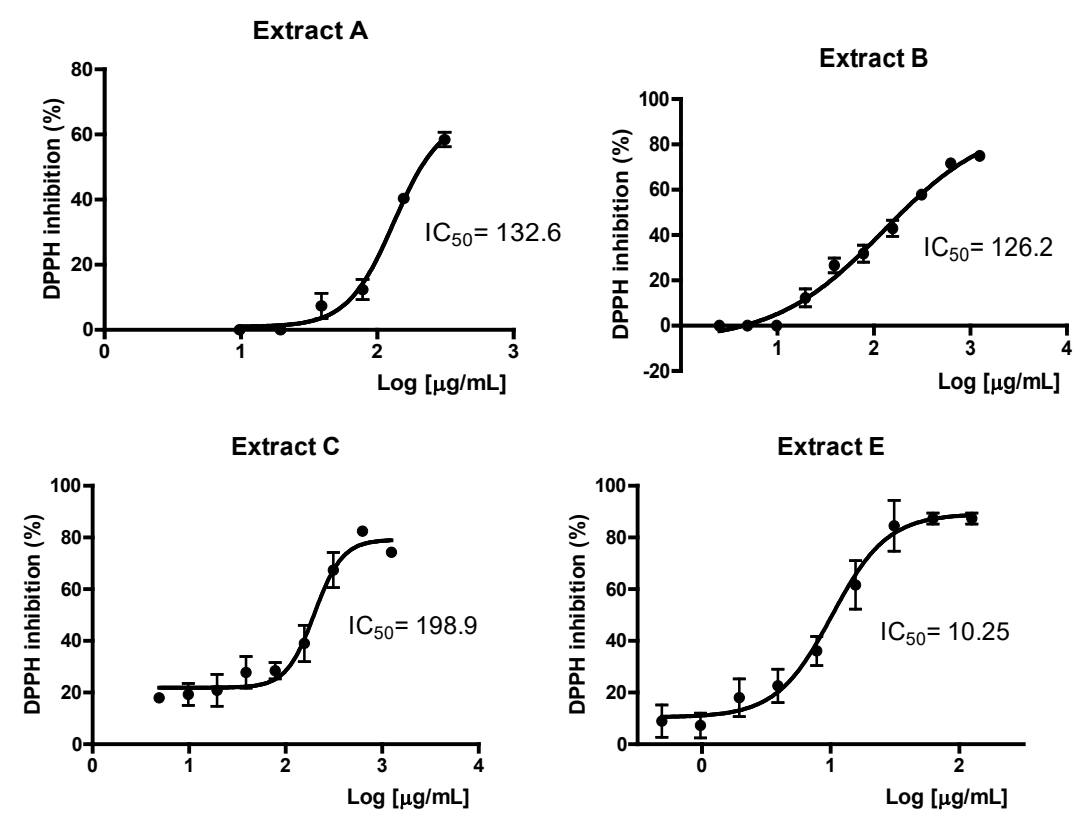

Fig. 3. Antioxidant activity of the extracts from $C$. minor $\mathrm{L}$ leaves. $\mathrm{IC}_{50}$ values were determined by using GraphPad Prism program Version 5 and it was defined as the total antioxidant compound necessary to decrease the initial DPPH radical concentration by $50 \%$. The scavenging effect of each extract was calculated based on the percentage of DPPH scavenged as: \% DPPH inhibition $=($ control Abs - sample Abs $) /($ control Abs) x 100, were control Abs represent: ethanol Abs + DPPH and sample Abs: sample Abs + DPPH. Values represent average of three determinations with \pm standard deviation. Ascorbic acid was used as standard.

Besides, our results showed $C$. minor L. leaves extracts only significantly $(\mathrm{p}<0.05)$ attenuated the oil croton-induced inflammation in mice at $4 \mathrm{mg}$ per ear (Table 3), except extract B that was able to significant reduce the inflammation at the dose of $2 \mathrm{mg}$ per ear. These extracts exhibited the highest percentage of the inhibition of the oil croton induced-inflammation showing values in the order of $82 \%$.

Table 3. Effect of C. minor leaves extracts on croton oil-induced oedema in the mouse ear.

\begin{tabular}{|c|c|c|c|c|c|c|c|c|c|}
\hline & \multirow[t]{2}{*}{ Dose } & \multicolumn{2}{|c|}{ Extract A } & \multicolumn{2}{|c|}{ Extract B } & \multicolumn{2}{|c|}{ Extract $\mathrm{C}$} & \multicolumn{2}{|c|}{ Extract E } \\
\hline & & $\begin{array}{c}\text { Oedema } \\
\text { weight } \\
(\mathrm{mg})\end{array}$ & $\begin{array}{c}\text { Inhibition } \\
(\%)\end{array}$ & $\begin{array}{c}\text { Oedema } \\
\text { weight } \\
(\mathrm{mg})\end{array}$ & $\begin{array}{c}\text { Inhibition } \\
(\%)\end{array}$ & $\begin{array}{c}\text { Oedema } \\
\text { weight } \\
\text { (mg) }\end{array}$ & $\begin{array}{c}\text { Inhibition } \\
(\%)\end{array}$ & $\begin{array}{c}\text { Oedema } \\
\text { weight } \\
(\mathrm{mg})\end{array}$ & $\begin{array}{c}\text { Inhibition } \\
(\%)\end{array}$ \\
\hline $\begin{array}{c}\text { Croton } \\
\text { oil } \\
\end{array}$ & & $\begin{array}{c}10.8 \pm \\
1.9 \\
\end{array}$ & - & $\begin{array}{c}10.8 \pm \\
1.9 \\
\end{array}$ & - & $10.8 \pm 1.9$ & - & $\begin{array}{c}10.8 \pm \\
1.9 \\
\end{array}$ & - \\
\hline \multirow{4}{*}{$\begin{array}{c}\text { Clusia } \\
\text { minor } \\
\text { extracts }\end{array}$} & 0.5 & $8.9 \pm 4.4$ & 17.4 & $9.9 \pm 1.2$ & 8.3 & $10.6 \pm 1.4$ & 1.2 & $9.5 \pm 1.4$ & 11.6 \\
\hline & 1 & $6.1 \pm 0.4$ & 43.9 & $5.9 \pm 0.7$ & 45.7 & $8.8 \pm 1.6$ & 18.1 & $7.9 \pm 0.8$ & 26.7 \\
\hline & 2 & $5.2 \pm 1.3$ & 51.5 & $5.2 \pm 1.6$ & 51.7 & $8.4 \pm 1.9$ & 22.0 & $6.6 \pm 1.8$ & 38.8 \\
\hline & 4 & $3.1 \pm 1.5$ & 71.3 & $1.9 \pm 0.9$ & 82.3 & $6.7 \pm 2.4$ & 38.3 & $3.4 \pm 2.7$ & 68.7 \\
\hline $\begin{array}{c}\text { Control } \\
+\end{array}$ & 3 & $0.6 \pm 0.1$ & 94.3 & $0.6 \pm 0.1$ & 94.3 & $0.6 \pm 0.1$ & 94.3 & $0.6 \pm 0.1$ & 94.3 \\
\hline
\end{tabular}

Each group represents the mean \pm S.E.M. of 7-10 animals. Dose, expressed in $\mathrm{mg} / \mathrm{ear}$.

Control +: Indomethacin ( $3 \mathrm{mg} / 20 \mu \mathrm{L}$ of acetone), ${ }^{*} \mathrm{p} \leq 0.05$ statistical significance compared to Croton oil group. 
The effects on cell viability were also evaluated in all extracts, and a significant decrease in cell viability was observed after exposure to cell lines during 48 hours to four evaluated extracts. Table 4 shows the $\mathrm{IC}_{50}$, concentration capable of inhibit the $50 \%$ of the cell viability, calculated for each extract. In general terms, the data shows that cell viability decreased after the exposure to the extracts from $C$. minor. The viability of the CT26 colon cancer cells was the least affected. Meanwhile, extract B seems to be the most cytotoxic under our experimental conditions, showing $\mathrm{IC}_{50}$ values of 32.01 for EA.hy 926 and $93.42 \mu \mathrm{g} / \mathrm{ml}$ for 4T1 cells. Cell viability was also reduced for BHK cells when exposed to extract B, but the effect was lesser because $\mathrm{IC}_{50}$ was $200.5 \mu \mathrm{g} / \mathrm{ml}$.

Sesquiterpenes have shown cytotoxic activity against several solid tumor cell lines [21]. Lupeol [30, 31], $\alpha$ and $\beta$-amyrins [32], squalene [47], stigmasterol [33, 42], sitosterol [31, 33, 48, 49] have shown cytotoxic activity and capacity to inhibit tumor promotion in cells. Thus, further studies should be achieved to determine which components of this species could be responsible for the cytotoxic activity specifically, and the pharmacological mechanisms involved.

A risk-benefit balance is an important focal point when new candidates are being tested experimentally. In this sense, acute toxicity studies represent the first step for predicting risk-benefit balance of them. Thus, at the end of this characterization, we decided to evaluate acute toxicity potential, with focus on possible neurotoxicity of $C$. minor extracts. No deaths were obtained after the oral dose administered of the extracts $(2000 \mathrm{mg} / \mathrm{kg})$ in both sexes in mice. However, it was observed some signs of toxicity during the first hours after administration of the extracts, being the most significant ones ptosis and increasing the grooming behavior and reduced explorative activity. They were more pronounced in the animals treated with extracts $\mathrm{C}$ and $\mathrm{E}$. The increase of the grooming behavior could be related to a central excitation or sympathetic stimulation. The ptosis, an indicative of a possible sedative action, could be related to a reduced animal alertness due to probably CNS depressant effects of the extracts. But, the observed signs did not lead to the death of any of the animals; this effect appeared immediately after the exposure and the animals recovered their expected behavior between the first 24 hours after the administration. No gross macroscopic alterations were found at necropsy of the animals at the end of the study. Then, the four extracts obtained from C. minor L. leaves were considered as no toxic extracts (unclassified products, according OECD 423 protocol) under our experimental conditions, since a dose of $2000 \mathrm{mg} / \mathrm{kg}$ did not deaths were observed.

Table 4. Effects of C. minor L. leaves extracts on cell viability.

\begin{tabular}{|c|c|c|c|}
\hline \multirow{4}{*}{ Cell line } & Extract & $\begin{array}{c}\text { Maximum } \\
\text { Effect* }\end{array}$ & $\begin{array}{c}\mathbf{I C}_{\mathbf{0}} \\
(\boldsymbol{\mu g} / \mathbf{m L})\end{array}$ \\
\hline \multirow{4}{*}{ BHK } & $\mathrm{A}$ & 53 & 129.60 \\
\cline { 2 - 4 } & $\mathrm{B}$ & 60 & 109.3 \\
\cline { 2 - 4 } & $\mathrm{C}$ & 50 & 221.2 \\
\cline { 2 - 4 } & $\mathrm{E}$ & 56 & 249.3 \\
\hline \multirow{4}{*}{ ET1 } & $\mathrm{A}$ & 56 & 121.9 \\
\cline { 2 - 4 } & $\mathrm{B}$ & 60 & 93.42 \\
\cline { 2 - 4 } & $\mathrm{C}$ & 50 & 101.1 \\
\hline \multirow{4}{*}{ EA.hy926 } & $\mathrm{E}$ & 54 & 124.4 \\
\cline { 2 - 4 } & $\mathrm{A}$ & 51 & 22.56 \\
\cline { 2 - 4 } & $\mathrm{B}$ & 54 & 32.01 \\
\cline { 2 - 4 } & $\mathrm{C}$ & 41 & 105.5 \\
\hline \multirow{4}{*}{ CT26 } & $\mathrm{E}$ & 52 & 90.99 \\
\cline { 2 - 4 } & $\mathrm{B}$ & 5 & 353.1 \\
\cline { 2 - 4 } & $\mathrm{C}$ & 25 & 203.5 \\
\cline { 2 - 4 } & $\mathrm{E}$ & 3 & 470.8 \\
\hline
\end{tabular}

*Respect to percentage of inhibition of cell viability after $48 \mathrm{~h}$ to exposure to the different concentration extracts.

IC 50 , concentration capable of inhibit the $50 \%$ cell viability. 
As our results show, the extracts from C. minor grown in Cuba are composed of several phytochemical compounds whose diverse bioactive effects have been here documented. Many of the compounds identified in the extracts are known to be pleiotropic, producing multiple effects by acting on several cellular and/or molecular targets. Taking into consideration the important role that oxidative stress and inflammation play in the development of various human diseases, including neurodegeneration and cancer, the activities found by us reasonably sustain the potential use of compounds extracted from C. minor as natural antioxidants with consequent health benefits. However, before final recommendations should be made, it would be necessary to achieve further studies to assess the relevance of such properties on other in vitro and in vivo pharma-toxicological models.

\section{Conclusions}

GC/MS analysis of ethyl acetate and methanol extracts of $C$. minor L. leaves allowed the identification of 33 and 27 compounds, respectively. Hydrocarbons composition was abundant and diverse. The ethyl acetate extract contained carboxylic acids including their derivatives, unsaturated hydrocarbons and the methanol extract were rich in alkanes or paraffin compounds. The abundance of vitamin $\mathrm{E}$ in the extracts is of relevant importance due to its pharmacological properties and its current use in modern life. The extracts obtained from C. minor L. grown in Cuba showed antioxidant, cytotoxic and anti-inflammatory properties and no acute toxicity effects in mice, suggesting the potential use of this specie as a new source of medicinal natural products for the prevention and management of human diseases.

\section{Acknolwedgements}

This work was partially supported by Visiting Research Program (PVE -Research Project, No. 400768/2014-3), CNPq, Brasil

\section{References}

1. Nogueira P.C.; Bittrich V.; Shepherd G.J.; Lopes A.V.; Marsaioli A.V. Phytochemistry 2001, 56, 443-452.

2. Peraza-Sánchez S.R.; Pacheco F.; Noh-Chimal A. Fitoterapia 2007, 78, 315-318.

3. Lastres M.; Ruiz-Zapata T.; Castro M.; Torrecilla P.; Lapp M.; Hernández-Chong L.; Muñoz D. Pittieria 2015, 39, 59-89.

4. Compagnone R.S.; Suarez A.C.; Leitão S.G.; Delle Monache F. Engl. Braz. J. Pharmacog. 2008, 18, 6-10.

5. Cuesta-Rubio O.; Piccinelli A.L.; Rastrelli L. Stud. Nat. Prod. Chem. 2005, 32, 671-720.

6. Popolo A.L.; Piccinelli S.M.; Rosalinda S.; Cuesta Rubio O.; Luca R.; Pinto A. Can. J. Physiol. Pharmacol. 2011, 89, 50-57.

7. Teixeira J.S.R.; Cruz F.G. Tetrahedron Lett. 2005, 46, 2813-2816.

8. Bailón-Moscoso N.; Romero-Benavides J.C.; Sordo M.; Villacís J.; Silva R.; Celi L.; MartínezVázquez M.; Ostrosky-Wegmanaet P. Braz. J. Pharmacog. 2016, 26, 44-49.

9. Ferreira R.O.; Carvalho Junior A. R.; Riger C.J.; Castro R.N.; Silva T.M.S.; Carvalho M. G. Quim. Nova. 2016, 39, 1093-1097.

10. Ribeiro P.R.; Ferraz C.G.; Guedes M.L.S.; Martins D.; Cruz F.G. Fitoterapia 2011, 82, 1237-1240.

11. Nunes J.S.F.; da Silva J.P.; Conserva L.M.; Barreto E. Chin. J. Nat. Med. 2013, 11, 385-390.

12. Ferreira R.O.; Carvalho Junior A.R.; Silva T.M.G.; Nora R.N.; Silva T.M.S.; Carvalho M.G. Braz. J. Pharmacog. 2014, 24, 617-625.

13. Farias J.A.; Ferro J.N.; Silva J.P.; Agra I.K.; Oliveira F.M.; Candea A.L.; Conte F.P.; Ferraris F.K.; Henriques M.; Conserva L.M.; Barreto E. Inflammation 2012, 35, 764-771. 
14. Díaz-Carballo D.; Gustmann S.; Acikelli A.H.; Bardenheuer W.; Buehler H.; Jastrow H.; Ergun S.; Strumberg D. Phytomedicine 2012, 19, 1298-1306.

15. Mangas R.; Bello A.; Cuesta-Rubio O.; Piccinelli A.L.; Rastrelli L. Lat. Am. J. Pharm. 2008, 27, 762-775.

16. Mangas R.; Montes de Oca R.; Bello A.; Vázquez A.N. Lat. Am. J. Pharm. 2008, 27, 747-751.

17. Tabart J. Food Chem. 2009, 133, 1226-1233.

18. Mosmann T. J. Immunol. Methods 1983, 65, 55-63.

19. Griswold D.E.; Martin L.D.; Badger A.M.; Breton J.; Chabot-Fletcher M. Inflamm. Res. 1998, 47, 56-61.

20. OECD Guideline for the testing of chemicals, No. 423. Acute oral toxicity acute toxic class method. Paris, France: Organization for Economic Cooperation and Development. 2000.

21. Neerman M.F. Inter. J. Aromather. 2003, 13, 114-120.

22. Mathur S.B. Phytochemistry 1972, 11, 1513-1514.

23. Hasbun-Pacheco C.; Calvo-Pineda M.A.; Barrios-Chica M.; Arguedas-Campos E.; Calvo A.; Jiménez R.; Poveda-Alvarez L.J. Ing. Cienc. Química 1985, 9, 96-97.

24. Farfan M.; Martinez E.; Delle Monache F. Rev. Colomb. Quim. 1998, 27, 87-89.

25. Desbois A.P., Smith V.J. Appl. Microbiol. Biotechnol. 2010, 85, 1629-42.

26. Graikou K., Suzanne K., Nektarios A., George S., Niki C., Efstathios G., Ioanna C. Chem.Cent. J. 2011, 5, 1-9.

27. Aparna V., Dileep K.V., Mandal P.K., Karthe P., Sadasivan C., Haridas M. Chem. Biol. Drug Des. 2012, 80, 434-439.

28. Saleem M. Cancer Lett. 2009, 285, 109-115.

29. Han N., Bakovic M. J. Bioanal. Biomed. 2015, S12: 005. doi:10.4172/1948-593X.S12-005

30. Gallo M.B.C.; Sarachine M.J. Int. J. Biomed. Pharmaceut. Sci. 2009, 3, 46-66.

31. Kuete V.; Krusche B.; Youns M.; Voukeng I.; Fankam A.G.; Tankeo S.; Lacmata S.; Effert T. $J$. Ethnopharmacol. 2011, 134, 803-812.

32. Hernández L.; Palazon J.; Navarro-Ocaña A. in: Phytochemicals-A Global Perspective of Their Role in Nutrition and Health. Dr. Venketeshwer, R. Ed., InTech, Rijeka, Croatia, 2012, 487-510.

33. Bouic, P.J. Curr. Opin. Clin. Nutr. Metab. Care. 2001, 4, 471-475.

34. Bouic P.J.; Lamprecht J.H. Altern. Med. Rev. 1999, 4, 170-177.

35. Loizou S.; Lekakis I.; Chrousos G.P.; Moutsatsou P. Mol. Nutr. Food Res. 2010, 54, 551-558.

36. Cao G.; Sofic, E.; Prior R.L. Free Radic. Biol. Med. 1997, 22, 749-760.

37. Chem Z.Y.; Cham P.T.; Ho, K.Y.; Fung K.P.; Wang J. Chem. Phys. Lipids. 1996, 79, 157-163.

38. Heim K.; Tagliaferro A.; Bobilya D.J. J. Nutr. Biochem. 2002, 13, 572-584.

39. Se-Youm A.; Asres K.; El-Fiky F. Phytochemistry 2006, 67, 2058-2070.

40. Van A.S.; Van D.; Tromp M.; Griffioen D.; Van B.; Van D.V.; Bast A. Free Radic. Biol. Med. 1996, 20,331-342.

41. Singh K.; Bhori M.; Marar T. Hum. Exp. Toxicol. 2015, 34, 380-389.

42. Hamdan D.; El-Readi M.Z.; Tahrani A.; Herrmann F.; Kaufmann D.; Farrag N.; El-Shazly A.; Wink M. Z. Naturforsch C 2011, 66, 385.

43. Kaur N.; Chaudhary J.; Jain A.; Kishore L. Int. J. Pharm. Sci. Res. 2011, 2, 2259-2265.

44. Baskar A.A.; Al Numair K.S.; Paulraj M.G.; Alsaif M.A.; Al Muamar M.; Ignacimuthu, S.; J. Med. Food. 2012, 15, 335-43.

45. Vivancos M.; Moreno J.J. Free Radic. Biol. Med. 2005, 39, 91-97.

46. Gupta A.; Sharma A.K.; Dobhal M.P.; Sharma M.C.; Gupta R.S. J Diabetes 2011, 3, 29-37.

47. Raman B.V.; La S.; Saradhi M.P.; Rao B.N.; Khrisna A.N.V.; Sudhakar M.; Radhakrishnan T. Asian J. Pharm. Clin. Res. 2012, 5, 99-106.

48. Ju Y.H.; Clausen L.M.; Allred K.F.; Almada A.L.; Helferich W.G. J. Nutr. 2004, 134, 1145-1151.

49. Ovesna Z.; Vachalkova A.; Horvathova K. Neoplasma 2004, 51, 407-414. 